\title{
Habitat use, activity patterns and human interactions with jaguars Panthera onca in southern Belize
}

\author{
Michael T. Dobbins, Michael K. Steinberg \\ EBEN N. BROADBENT and SADIE J. RYAN
}

\begin{abstract}
Parts of southern Belize are designated as a corridor for the jaguar Panthera onca but the Maya region remains understudied. We therefore studied jaguar habitat use, activity patterns, and interactions with people in Blue Creek, a Maya village in a human-dominated tropical landscape in southern Belize. We used camera traps to detect jaguar presence, and interviews to assess local people's attitudes to and perceptions of jaguars. We recorded 28 independent photographic events during 1,200 camera-trap nights (i.e. a relative abundance index of 2.3 jaguars per 100 trap days). Seven individual jaguars were identified. Jaguars preferred lowland broad-leaf tropical forest and were detected more often during daylight, in contrast to findings from previous studies. Attitudes towards jaguars were largely positive: $88 \%$ of respondents $(n=48)$ did not fear jaguars living around the village, and $81 \%$ understood the positive effect that jaguars have on the ecosystem. Although $92 \%$ of respondents reported seeing a jaguar within the previous 2 years, attacks on livestock in the village were rare, with only two occurrences in the previous 3 years. Ecotourism has grown rapidly in Belize in recent years, and Blue Creek is home to several natural tourist attractions and an eco-lodge that brings tourists, school groups, and researchers to the village. Ecotourism has provided an economic incentive for village investment in conservation, and $94 \%$ of respondents stated that preservation of wildlife, including jaguars, was beneficial to their wellbeing.
\end{abstract}

Keywords Activity patterns, Belize, community conservation, conservation corridor, habitat use, human-jaguar interaction, jaguar, well-being

Supplementary material for this article is available at https://doi.org/10.1017/Soo30605317000308

Michael Dobbins (Corresponding author) and SADie Ryan Department of Geography, University of Florida, 3141 Turlington Hall, P.O. Box 117315, Gainesville, Florida 32611, USA. E-mail michaeltdobbins@ufl.edu

Michael Steinberg Department of Geography, University of Alabama, Tuscaloosa, USA

EBEN BRoAdBent School of Forest Resources \& Conservation, University of Florida, Gainesville, USA

Received 10 May 2016. Revision requested 4 August 2016.

Accepted 22 February 2017. First published online 19 September 2017.

\section{Introduction}

The jaguar Panthera onca is the largest felid in the 1 Americas, with a historical range extending from southern USA to Argentina (Zeller, 2007). Anthropogenic factors such as habitat destruction and fragmentation, illegal hunting, and hunting of the jaguar's prey species have led to an estimated $40 \%$ decrease in the jaguar's range (Zeller, 2007), and the species is categorized as Near Threatened on the IUCN Red List (Caso et al., 2008). Further range reduction will lead to smaller effective population sizes (Reed et al., 2003) and increase the frequency of human-jaguar interactions, as jaguars are forced into more humandominated landscapes (Foster et al., 2010a).

Belize is particularly important for jaguar conservation as it is a corridor between populations in Guatemala and Mexico and the rest of Central America. Approximately $60 \%$ of Belize's forests are intact (Cherrington et al., 2010) but economic development and agriculture pose threats to the connectivity of Belize's jaguar corridor, a least-cost conservation corridor designed by the wild felid research group Panthera to link core jaguar populations within human-dominated landscapes (Rabinowitz, 2006; Rabinowitz \& Zeller, 2010).

Jaguars occur in a variety of habitats but previous studies have shown they prefer tropical lowland environments at $<1,200 \mathrm{~m}$ altitude (Sunquist \& Sunquist, 2002), in close proximity to water (Monroy-Vilchis et al., 2009; Foster et al., 2010a). Jaguars are predominantly active at night and just before dawn (Maffei et al., 2002; Nunez et al., 2002; Scognamillo et al., 2002; Foster et al., 2010a,b; Harmsen et al., 2011). The increase in agricultural and residential development across Latin America continues to bring people and jaguars into direct conflict (Polisar et al., 2003) but few studies have investigated jaguar populations in a community landscape (Figel et al., 2011; Petracca et al., 2014).

Previous studies examining the effects of human disturbance on jaguar populations in Belize focused on central and northern Belize (Rabinowitz, 1986; Silver et al., 2004; Weckel et al., 2006; Kelly et al., 2008; Harmsen et al., 2009; Foster et al., 2010a; Davis et al., 2011), and thus the species' status in the southernmost district of Toledo was largely unknown. The Toledo landscape is dominated by the activities of $>30$ Mopan and Kekchi Maya villages, whose inhabitants practise slash and burn agriculture (Steinberg, 1998). Despite human disturbance and forest fragmentation within the 
Maya region, preliminary surveys in Blue Creek in 2013 indicated that jaguars and other felids routinely traverse the region (MS, pers. obs.).

Previous studies found that most residents did not feel threatened by the presence of jaguars, and understood the significance of their conservation (Conforti \& de Azevedo, 2003; Campbell \& Alvarado, 2011; Figel et al., 2011). However, livestock predation remains a major cause of human-jaguar conflict (Rabinowitz, 1986; Zimmermann et al., 2005; Rosas-Rosas et al., 2008; Marchini \& Macdonald, 2012; Zarco-González et al., 2013). Although Maya villages in southern Belize do not typically keep cattle (MD, pers. obs.), an abundance of chickens, pigs and small domestic dogs $(<16 \mathrm{~kg})$ range freely throughout the communities, possibly luring jaguars into residential areas.

We integrated wildlife and social survey methods to quantify the jaguar's habitat use, activity patterns, and interactions with people in the Maya region of southern Belize. Jaguar presence and habitat use were identified using camera traps, and interviews were conducted with village residents to understand perceptions of, and interactions with, jaguars. This study provides a baseline and framework for future studies in the region and could inform a comprehensive jaguar conservation strategy for the Toledo district and Maya communities.

\section{Study area}

The study area comprised $25 \mathrm{~km}^{2}$ around Blue Creek, a Maya village in Belize's southernmost district, Toledo (Fig. 1). The four major habitat types are submontane broadleaf forest, lowland broad-leaf forest, swamp, and agriculture (MD, pers. obs.), at elevations of $20-430 \mathrm{~m}$. Mean daily temperature is $30^{\circ} \mathrm{C}$ in summer and $26^{\circ} \mathrm{C}$ in winter, and mean annual precipitation is $3,048-3,556 \mathrm{~mm}$, with precipitation occurring mainly during July-December (BERDS, 2010). Blue Creek has c. 300 residents of Mopan and Kekchi Maya heritage. The primary occupation of men is farming, whereas women are engaged primarily in childcare and household tasks. Men hunt several mammal species around the village, including the paca Agouti pacas, whitetailed Odocoileus virginianus and red brocket deer Mazama americana, and white-lipped Tayassu pecari and collared peccaries Pecari tajacu, all of which are also important prey species for the jaguar (Foster et al., 2010b).

\section{Methods}

The study was conducted during May-August 2014.

Track plotting In May 2014 we surveyed the study area for jaguar sign (scats, tracks and recent kills). We deployed cameras on existing man-made and game trails throughout the study area. Potential camera sites were rated and selected according to location and presence of jaguar sign, following Wallace et al. (2003), with sites categorized as excellent (jaguar sign present), good (no jaguar sign, but sign of prey species present), or poor (no sign of jaguars or prey species). We chose nine excellent and six good sites $(n=15)$, and attempted to sample the four habitat types proportionally, subject to site quality. The locations of the camera stations were recorded with a global positioning system and analysed using ArcGIS v. 10.2 (ESRI, Redlands, USA) (Fig. 1). There was a mean distance of $1.1 \pm \mathrm{SD} 0.77 \mathrm{~km}$ between neighbouring camera stations, with a maximum of $7 \mathrm{~km}$ between any two stations.

Camera trapping We used infrared motion-activated trail cameras (Strike Force; Browning, Morgan, USA), running 24 hours per day, with a $30 \mathrm{~s}$ minimum time delay between pictures to prevent multiple images of lingering individuals or herding species. Fifteen stations were deployed but three were lost to theft. Data were collected from 12 stations during May-August 2014, with 1,200 camera-trap days in total. Each station comprised two cameras facing perpendicular to the trail, for optimal lateral viewing of passing wildlife. We could thus identify individual jaguars by unique spot patterns in their coats. Multiple photographs of the same individual within 1 hour were excluded to preserve independent events. A relative abundance index was calculated as the number of independent photographs per 100 trap-days. Habitat use was quantified as the relative abundance index of jaguars for each habitat type. Habitat preference was assessed using $\chi^{2}$ analysis, following the methods of Neu et al. (1974), which have also been used by other researchers to quantify jaguar habitat use (Scognamillo et al., 2003; Monroy-Vilchis et al., 2009).

Social surveys Human-jaguar interactions in Blue Creek were quantified by interviewing local residents. Social surveys (Supplementary Material) were created in collaboration with the village council chairman and secretary, conforming to the standards set out in the ethical guidelines of the Social Research Association (SRA, 2003). In Blue Creek, men spend most of their time outdoors farming and hunting, whereas women rarely leave the residential area of the village, and therefore we interviewed men only, as they were better able to identify jaguars and more likely to have interactions with them. There are c. 6o households in Blue Creek, and we interviewed 48 male heads of households. Interviews were conducted in English, with a village representative present to translate into Mopan or Kekchi if required. We recorded the date, time, location and nature of encounters with jaguars reported to have occurred in the previous 3 


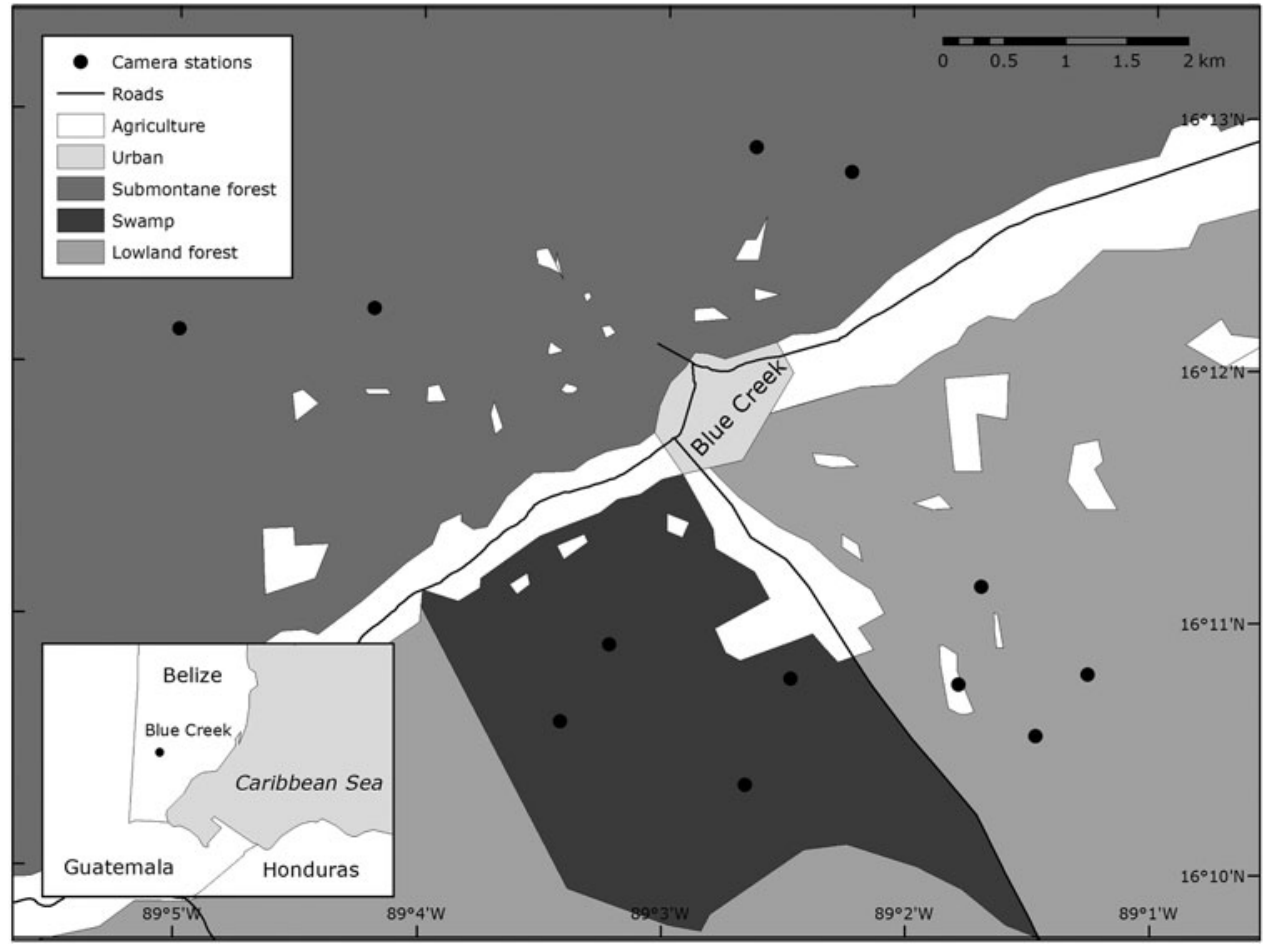

FIG. 1 Locations of camera stations in various habitat types in the study area around the Maya village of Blue Creek, Belize. years. Respondents were asked to identify all five native cat species from photographs. If they did not identify the native species correctly their interview data were not analysed. concolor were present in the study area $(\mathrm{n}=5$ individuals identified) but were active only at night.

\section{Results}

\section{Camera data}

We obtained 28 independent photographs of jaguars (Table 1), comprising seven unique individuals. Three photographs could not be assigned to an individual. The relative abundance index was 2.3, and jaguars were detected at $58 \%$ ( 7 of 12 ) of camera stations. The maximum number of captures at a single station was seven per 100 trap days. Five jaguars were recorded at more than one station, and the maximum distance between detections of the same individual was $4 \mathrm{~km}$. Habitat use was not correlated with the area of habitat type and there was a significant difference in habitat type use $\left(\chi_{3}^{2}=12.511, \mathrm{P}<0.005\right)$, indicating habitat preference. Although submontane broad-leaf forest $(>300 \mathrm{~m}$ elevation) was the most extensive habitat type, jaguars were rarely present there $(11 \%)$. Detections were most common in lowland tropical broad-leaf forest $(<100 \mathrm{~m}$ elevation; $61 \%)$ and swamp (25\%). One jaguar was detected in an agricultural area (3\%).

Jaguars were most active in the daytime ( 25 of 28 photographs; 89\%), during 13.00-18.00 (Fig. 2). There were only three records of activity at night, and they were not specific to a camera station or habitat type. Sympatric pumas Puma

\section{Social data}

The mean age of respondents was $42 \pm$ SD 9.6 years (range 24-65 years). Their reported primary occupations were farming (90\%), tourist guide (6\%) and government (police or military; $4 \%$ ). Nearly all respondents reported having seen a jaguar in the previous 2 years (92\%), and many had seen jaguars on more than one occasion. Some respondents reported seeing pumas (14\%) but said they were rare in the area. A total of 71 jaguar sightings were recorded from 44 individuals. Most sightings occurred near the respondents' farms $(52 \%), 25 \%$ were of jaguars crossing roads, and $23 \%$ occurred while hunting in the forest block. All reported sightings occurred within the study area.

Attitudes towards jaguars were mostly positive. Although the majority of respondents reported seeing jaguars recently, few reported negative interactions between jaguars and village residents. Within the previous 3 years there had been only two reported occurrences of jaguar attacks on residents' dogs or livestock: in one incident a respondent's dog was attacked while the respondent was hunting near his farm, and in the other a jaguar entered the village at night and killed one of the respondent's chickens. In both cases the respondents witnessed the attack and killed the jaguar in retaliation. Nonetheless, the majority of respondents $(88 \%)$ stated that they did not fear jaguars living near the 
TABLE 1 Camera-trap capture rates of jaguars Panthera onca and their prey species across four habitat types around Blue Creek village in southern Belize (Fig. 1) during May-August 2014.

\begin{tabular}{|c|c|c|c|c|c|c|c|}
\hline & \multicolumn{6}{|c|}{ No. of captures } & \multirow[b]{2}{*}{ Tota } \\
\hline & $\begin{array}{l}\text { Jaguar } \\
\text { Panthera } \\
\text { onca }\end{array}$ & $\begin{array}{l}\text { Collared } \\
\text { peccary Pecari } \\
\text { tajacu }\end{array}$ & $\begin{array}{l}\text { White-tailed deer } \\
\text { Odocoileus } \\
\text { virginianus }\end{array}$ & $\begin{array}{l}\text { Red brocket } \\
\text { deer Mazama } \\
\text { americana }\end{array}$ & $\begin{array}{l}\text { Armadillo Dasypus } \\
\text { novemcinctus }\end{array}$ & $\begin{array}{l}\text { Lowland paca } \\
\text { Agouti paca }\end{array}$ & \\
\hline Lowland forest $^{1}$ & 17 & 8 & 10 & 0 & 5 & 20 & 60 \\
\hline Submontane forest ${ }^{2}$ & 3 & 9 & 2 & 0 & 10 & 14 & 38 \\
\hline Swamp ${ }^{3}$ & 7 & 0 & 15 & 10 & 0 & 0 & 32 \\
\hline Agriculture $^{4}$ & 1 & 0 & 3 & 0 & 5 & 9 & 18 \\
\hline Total & 28 & 17 & 30 & 10 & 20 & 43 & 148 \\
\hline
\end{tabular}

${ }^{1}$ Three stations, 300 trap nights

${ }^{2}$ Four stations, 400 trap nights

${ }^{3}$ Four stations, 400 trap nights

${ }^{4}$ One station, 100 trap nights

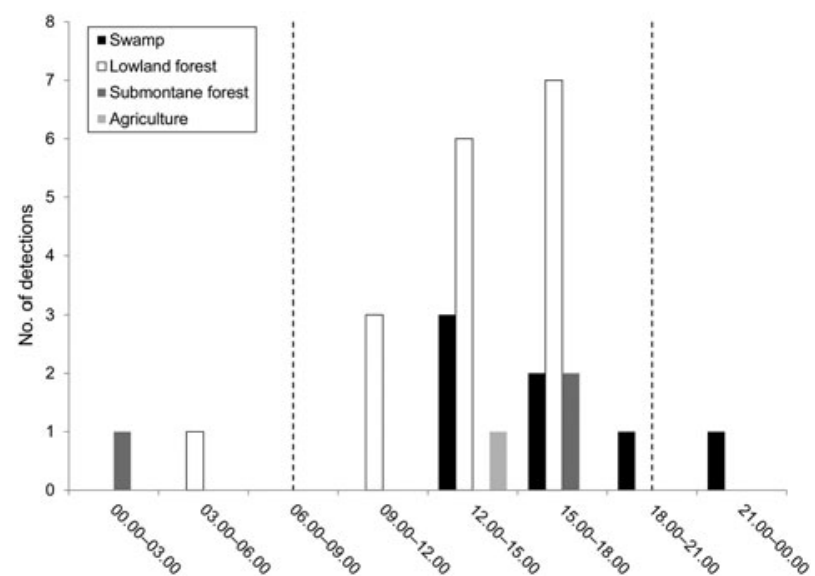

Fig. 2 Temporal variation in jaguar Panthera onca activity in the four main habitat types in Blue Creek, Belize (Fig. 1), based on the number of independent photographic records per habitat type. The dashed vertical lines represent sunrise and sunset.

village, and only $4 \%$ stated they would attempt to kill a jaguar on sight.

Blue Creek has a biological field station, which brings in hundreds of guests per year and supports the local economy. The field station is owned by International Zoological Expedition Belize and serves as an eco-lodge for tourists, student groups and researchers. It is locally managed, so many families benefit economically by working as cooks or tour guides, and making crafts to sell to visitors. Nearly all respondents (94\%) reported that the presence of jaguars and other charismatic wildlife had positively affected ecotourism and that the conservation of these species and their habitat would benefit them.

\section{Discussion}

This is the first camera-trap study conducted to record jaguar presence in the Maya communities of southern Belize.
Seven individual jaguars were identified in a study area considerably smaller than a jaguar's home range (up to $40 \mathrm{~km}^{2}$ in the tropical forests of Belize, Rabinowitz \& Nottingham, 1986; and up to $142 \mathrm{~km}^{2}$ in the Pantanal region of Brazil, Quigley \& Crawshaw, 1992). With a mean distance of $1.1 \mathrm{~km}$ between camera stations, there was a high probability of capturing any permanent or transient jaguars in the area. Although the study precluded identifying permanent and transient individuals, the number of jaguars identified in this small rural village suggests significant overlapping of home ranges (as shown by Quigley \& Crawshaw, 1992; Harmsen et al., 2009).

Of the four major habitat types the largest number of photographic detections were in lowland forest. In addition to being preferred jaguar habitat, lowland forest also had the highest availability of the jaguar's preferred prey species: armadillos Dasypus novemcinctus, collared peccaries, and white-tailed and red brocket deer (Table 1). There was also a high probability of human-jaguar interaction in lowland forest, as most trail networks in this area had high human foot traffic.

Despite being the most extensive habitat type, submontane forest had the least number of jaguar detections. This area had less human traffic than other habitat types but also had fewer trails to traverse the rugged terrain. Preferred prey species and water availability were scarce, and the few puma sightings occurred exclusively in this region, suggesting spatial avoidance between the two felid species.

The swamp habitat is separated from lowland forest by an elevated road running from Blue Creek to Santa Theresa. This road acts as a dam during the rainy season, and seasonal flooding occurs in much of the swamp habitat. There was a considerable difference in the number of detections of jaguars and their prey species between the two neighbouring habitats. Of the jaguar's preferred prey species, only deer were present in the swamp (Table 1). 
Although the number of jaguar detections was higher in swamp than in submontane forest and agricultural areas, it was considerably lower than in lowland forest.

The agricultural areas of Blue Creek comprise mostly milpa farms (multi-crop fields that are routinely slashed and burned) and milpa buffer zones bordering the other habitat types. Many small mammal species, including preferred prey of the jaguar, were present in these areas, perhaps lured by crops and fruit. Many hunters reported that they frequently hunted on or near their farms because of the abundance of game.

Most previous studies found that jaguars are active predominantly at night (Maffei et al., 2002; Nunez et al., 2002; Scognamillo et al., 2002; Harmsen et al., 2009), but the jaguars in our study area were rarely active at night. The majority of jaguar sightings occurred during 13.00-18.00, coinciding with high human activity around the village and nearby trail networks. In contrast, preferred prey were found to be mostly nocturnal (except for deer), and neither jaguars nor prey showed significant geographical variation in their activity patterns. The contrast in hourly activity patterns between the diurnal jaguars of Blue Creek and the primarily nocturnal jaguars in nearby Cockscomb Basin Wildlife Sanctuary (Harmsen et al., 2009) warrants further investigation.

The perception of jaguars at Blue Creek was largely positive, overall, probably because of the jaguar's cultural, ecological and economic importance to the community. Blue Creek exemplifies the benefits ecotourism can have for the local community and the environment. However, the majority of Maya villages in this region do not have sufficient ecotourism to provide economic incentives for supporting environmental sustainability and conservation. Future studies should investigate the role of economic support in a community's perception of jaguars by also surveying Maya villages that do not have substantial ecotourism.

Our findings have significant implications for the status of jaguars and jaguar conservation in the Maya region of Belize. The future of jaguars in this region depends upon the preservation of suitable habitat and ensuring adequate connectivity between neighbouring forests. As jaguars live in close proximity to people, there is a need for community involvement in conservation efforts. Economic incentives (e.g. ecotourism) have had a positive effect on people's attitudes towards jaguars in Blue Creek; however, investigation of other Maya communities is needed to develop a comprehensive regional jaguar conservation plan. Continuing educational efforts to communicate the ecological importance of jaguars for both the environment and communities, combined with community-based conservation initiatives, can help secure the persistence of jaguar populations in southern Belize.

Continuation of this work has expanded across more than 2,000 $\mathrm{km}^{2}$ of both protected areas and Maya communities in southern Belize. We are currently investigating jaguar and prey species movement across the landscape, as well as conducting interviews with five additional Maya villages to understand better regional human interactions with and attitudes towards jaguars.

\section{Acknowledgements}

This project was funded by the Wildlife Conservation Grant of Birmingham Zoo, USA, and the University of Alabama. We thank William Foster and Terra Manasco of the Birmingham Zoo for their support and contributions. We also thank the Belize Forest Department and Forest Officer Edgar Correa for their support (permit no. 23178-10701), and Heraldo Pop (Blue Creek Village Chairman) and Florencio Coc (Blue Creek Village Secretary) for their interest and collaboration in this project.

\section{Author contributions}

MD and MS conceived the study. MD designed the study and collected the data. MD, MS, EB and SR conducted data analysis and wrote the article.

\section{References}

BERDS (Biodiversity \& Environmental Resource Data System of Belize) (2010) Http://www.biodiversity.bz [accessed 2 March 2017].

Campbell, M.O. \& Alvarado, M.E.T. (2011) Public perceptions of jaguars Panthera onca, pumas Puma concolor and coyotes Canis latrans in El Salvador. Area, 43, 250-256.

Caso, A., Lopez-Gonzalez, C., Payan, E., Eizirik, E., DE Oliveira, T., Leite-Pitman, R. et al. (2008) Panthera onca. In The IUCN Red List of Threatened Species 2008: e.T15953A5327466. Http:// dx.doi.org/10.2305/IUCN.UK.2008.RLTS.T15953A5327466.en [accessed 1 March 2017].

Cherrington, E.A., Ek, E., Cho, P., Howell, B.F., Hernandez, B.E., Anderson, E.R. et al. (2010). SERVIR: forest cover and deforestation in Belize: 1980-2010. Technical report.

Conforti, V.A. \& De Azevedo, F.C.C. (2003) Local perceptions of jaguars (Panthera onca) and pumas (Puma concolor) in Iguaçu National Park area, south Brazil. Biological Conservation, 111, 215-221.

Davis, M.L., Kelly, M.J. \& Stauffer, D.F. (2011) Carnivore co-existence and habitat use in the Mountain Pine Ridge Forest Reserve, Belize. Animal Conservation, 14, 56-65.

Figel, J.J., Durán, E. \& Bray, D.B. (2011) Conservation of the jaguar Panthera onca in a community-dominated landscape in montane forests in Oaxaca, Mexico. Oryx, 45, 554-56o.

Foster, R.J., Harmsen, B.J. \& Doncaster, C.P. (2010a) Habitat use by sympatric jaguars and pumas across a gradient of human disturbance in Belize. Biotropica, 42, 724-731.

Foster, R.J., Harmsen, B.J., Valdes, B., Pomilla, C. \& Doncaster, C.P. (2010b) Food habits of sympatric jaguars and pumas across a gradient of human disturbance. Journal of Zoology, 280, 309-318.

Harmsen, B.J., Foster, R.J., Silver, S.C., Ostro, L.E.T. \& Doncaster, C.P. (2009) Spatial and temporal Interactions of 
sympatric jaguars (Panthera onca) and pumas (Puma concolor) in a Neotropical forest. Journal of Mammalogy, 90, 612-620.

Harmsen, B.J., Foster, R.J., Silver, S.C., Ostro, L.E.T. \& Doncaster, C.P. (2011) Jaguar and puma activity patterns in relation to their main prey. Mammalian Biology, 76, 320-324.

Kelly, M.J., Noss, A.J., Di Bitetti, M.S., Maffei, L., Arispe, R.L., Paviolo, A. et al. (2008) Estimating puma densities from camera trapping across three study sites: Bolivia, Argentina, and Belize. Journal of Mammalogy, 89, 408-418.

Maffei, L., Cuéllar, E. \& Noss, A.J. (2002) Uso de trampas-cámara para la evaluación de mamíferos en el ecotono Chaco-Chiquitanía. Revista Boliviana de Ecología y Conservación Ambiental, 11, 55-65.

Marchini, S. \& Macdonald, D.W. (2012) Predicting ranchers' intention to kill jaguars: case studies in Amazonia and Pantanal. Biological Conservation, 147, 213-221.

Monroy-Vilchis, O., Rodríguez-Soto, C., Zarco-GonzÁlez, M. \& URIOS, V. (2009) Cougar and jaguar habitat use and activity patterns in central Mexico. Animal Biology, 59, 145-157.

Neu, C.W., Byers, C.R. \& Peek, J.M. (1974) A technique for analysis of utilization-availability data. The Journal of Wildlife Management, $38,541-545$.

Nunez, R., Miller, B. \& Lindzey, F. (2002) Ecologi'a del jaguar en la Reserva de la Biosfera Chamela-Cuixmala, Jalisco, México. In El jaguar en el Nuevo Mileno. Una evaluacion de su estado, deteccion de prioridades y recomendaciones para la conservacio' $n$ de los jaguares en America (eds R.A. Medellín, C. Chetkiewicz, A. Rabinowitz, K. H. Redford, J.G. Robinson, E. Sanderson \& A. Taber), pp. 107-126. Universidad Nacional Autonoma de Mexico and Wildlife Conservation Society, Distrito Federal, Mexico.

Petracca, L.S., Ramírez-Bravo, O.E. \& Hernández-Santín, L. (2014) Occupancy estimation of jaguar Panthera onca to assess the value of east-central Mexico as a jaguar corridor. Oryx, 48, 133-140.

Polisar, J., Maxit, I., Scognamillo, D., Farrell, L., Sunquist, M. E. \& EISENBERG, J.F. (2003) Jaguars, pumas, their prey base, and cattle ranching: ecological interpretations of a management problem. Biological Conservation, 109, 297-310.

Quigley, H.B. \& Crawshaw, JR, P.G. (1992) A conservation plan for the jaguar Panthera onca in the Pantanal region of Brazil. Biological Conservation, 61, 149-157.

Rabinowitz, A.R. (1986) Jaguar predation on domestic livestock in Belize. Wildlife Society Bulletin, 14, 170-174.

Rabinowitz, A.R. (2006) Connecting the dots: saving the jaguar throughout its range. Wildlife Conservation Magazine, January/ February, 25-30.

Rabinowitz, A.R. \& Nottingham, B.G. (1986) Ecology and Behavior of the Jaguar (Panthera onca) in Belize, Central America. New York Zoological Society, New York, USA.

RabinowitZ, A.R. \& Zeller, K.A. (2010) A range-wide model of landscape connectivity and conservation for the jaguar, Panthera onca. Biological Conservation, 143, 939-945.

Reed, D.H., O'Grady, J.J., Brook, B.W., Ballou, J.D. \& Frankham, R. (2003) Estimates of minimum viable population sizes for vertebrates and factors influencing those estimates. Biological Conservation, 113, 23-34.

Rosas-Rosas, O.C., Bender, L.C. \& Valdez, R. (2008) Jaguar and puma predation on cattle calves in northeastern Sonora, Mexico. Rangeland Ecology \& Management, 61, 554-560.
Scognamillo, D., Maxit, I.E., Sunquist, M. \& Farrell, L. (2002) Ecología del jaguar y el problema de la depredación de ganado en un hato de los Llanos venezolanos. In El jaguar en el Nuevo Mileno. Una evaluacion de su estado, deteccion de prioridades y recomendaciones para la conservacio' $n$ de los jaguares en America (eds R.A. Medellín, C. Chetkiewicz, A. Rabinowitz, K.H. Redford, J.G. Robinson, E. Sanderson \& A. Taber), pp. 139-150. Universidad Nacional Autonoma de Mexico and Wildlife Conservation Society, Distrito Federal, Mexico.

Scognamillo, D., Maxit, I.E., Sunquist, M. \& Polisar, J. (2003). Coexistence of jaguar (Panthera onca) and puma (Puma concolor) in a mosaic landscape in the Venezuelan Ilanos. Journal of Zoology, 259, 269-279.

Silver, S.C., Ostro, L.E.T., Marsh, L.K., Maffei, L., Noss, A.J., KelLy, M.J. et al. (2004) The use of camera traps for estimating jaguar Panthera onca abundance and density using capture/ recapture analysis. Oryx, 38, 148-154.

SRA (Social Research Association) (2003) Ethical Guidelines. Http://the-sra.org.uk/wp-content/uploads/ethicso3.pdf [accessed 23 June 2017].

SteinberG, M.K. (1998) Mopan Maya forest resources in southern Belize. Geographical Review, 88, 131-137.

Sunquist, M. \& Sunquist, F. (2002) Wild Cats of the World. University of Chicago Press, Chicago, USA, and London, UK.

Wallace, R.B., Gomez, H., Ayala, G. \& Espinoza, F. (2003) Camera trapping for jaguar (Panthera onca) in the Tuichi Valley, Bolivia. Mastozoología Neotropical, 10, 133-139.

Weckel, M., Giuliano, W. \& Silver, S. (2006) Jaguar (Panthera onca) feeding ecology: distribution of predator and prey through time and space. Journal of Zoology, 270, 25-30.

Zarco-González, M.M., Monroy-Vilchis, O. \& Alaníz, J. (2013) Spatial model of livestock predation by jaguar and puma in Mexico: conservation planning. Biological Conservation, 159, 80-87.

Zeller, K. (2007) Jaguars in the New Millennium Data Set Update: The State of the Jaguar in 2006. Wildlife Conservation Society, New York, USA.

Zimmermann, A., Walpole, M.J. \& Leader-Williams, N. (2005) Cattle ranchers' attitudes to conflicts with jaguar Panthera onca in the Pantanal of Brazil. Oryx, 39, 406-412.

\section{Biographical sketches}

Michael Dobbins studies the impacts of anthropogenic disturbance on the biodiversity and abundance of wildlife and the implementation of conservation strategies in tropical landscapes. MichaEL Steinberg studies cultural and political ecology, remote sensing, and conservation of threatened species in Belize. EBEN BROADBENT is involved in projects linking social sciences with forest ecology, conservation biology and remote sensing, including projects investigating feedbacks between soil fertility and land use decision making. SADIE RYAN studies the anthropogenic impacts of land use change and conservation management in tropical landscapes, focusing on the multi-scale issues and interactions of human livelihoods, disease transmission, health interventions, landscape sustainability and local perceptions. 